\title{
POPULATION DYNAMICS OF EUGLOSSINAE BEES (HYMENOPTERA, APIDAE) IN AN EARLY SECOND-GROWTH FOREST OF CAJUAL ISLAND, IN THE STATE OF MARANHÃO, BRAZIL
}

\author{
SILVA, F. S. ${ }^{1}$ and REBÊLO, J. M. M. ${ }^{2}$ \\ ${ }^{1}$ Departamento de Patologia, Universidade Federal do Maranhão, Praça Madre Deus, 2, CEP 65025-560, \\ São Luís, MA, Brazil \\ ${ }^{2}$ Departamento de Biologia, Universidade Federal do Maranhão, Campus Bacanga, Avenida dos Portugueses s/n, \\ CEP 65080-040, São Luís, MA, Brazil \\ Correspondence to: Francinaldo S. Silva, Departamento de Patologia, Universidade Federal do Maranhão, Praça \\ Madre Deus, 2, CEP 65025-560, São Luís, MA, Brazil, e-mail: silviogm@ufma.br \\ Received January 25, 2000 - Accepted June 15, 2000 - Distributed February 28, 2002
}

(With 5 figures)

\begin{abstract}
A study was conducted in an early second-growth forest aiming at knowing the richness, relative abundance, seasonal distribution, and hourly frequency of euglossine bees, and their association with scent baits. Male bees were attracted to cineole, vanillin, methyl salicylate, and eugenol. The baits were hooked $1.5 \mathrm{~m}$ high and $6 \mathrm{~m}$ from one another. The specimens were collected from December 1997 to November 1998, once a month, from 7:00 to 17:00 h. A total of 339 male euglossine bees were caughts, accounting for 19 species and four genera. The most common species was $E$. cordata, making up $69.9 \%$ of the individuals, followed by E. truncata (2.3\%), E. violaceifrons, and E. smaragdina (2.1\%). The most attractive scent was cineole, which baited $87 \%$ of the specimens and $73.7 \%$ of the species. Vanillin, the second most visited bait, eured $7.6 \%$ of the specimens and $26.3 \%$ of the species. E. surinamensis was only collected with this bait. Methyl salicylate and eugenol baited combined $2.6 \%$ of the specimens. However, by species numbers Methyl salicylate attracted $21 \%$ whereas eugenol was attractive for $15.8 \%$ of them. In general, the species were more abundantly found in the rainy season (January-June). The hourly activity data showed that the euglossine bees were attracted to the baits all day long, but at a higher frequency in the morning period, peaking between 8:00 and 10:00 $\mathrm{h}$.
\end{abstract}

Key words: Euglossinae, Cajual Island, scent baits, Maranhão.

\section{RESUMO}

\section{Dinâmica de população de abelhas Euglossinae (Hymenoptera, Apidae) em uma área de capoeira da ilha de Cajual, Estado do Maranhão, Brasil}

Realizou-se o presente estudo em uma área de capoeira, objetivando conhecer a riqueza, a abundância relativa, a distribuição sazonal, a freqüência horária e a associação de espécies de Euglossinae com as iscas odoríferas. As abelhas (machos) foram atraídas por iscas de cineol, vanilina, salicilato de metila e eugenol, as quais encontravam-se a $1,5 \mathrm{~m}$ do solo e a uma distância de $6 \mathrm{~m}$ uma das outras. As coletas foram realizadas de dezembro/97 a novembro/98, uma vez por mês, das 7 às 17 horas. Foram amostrados 339 machos, distribuídos em 19 espécies e 4 gêneros. A espécie mais abundante foi E. cordata, representada por $69,9 \%$ dos indivíduos, seguida por E. truncata (2,9\%), E. violaceifrons e E. smaragdina (2,1\%). O composto mais atrativo foi o cineol, que atraiu $87 \%$ dos indivíduos e $73,7 \%$ das espécies. Vanilina atraiu 7,6\% dos indivíduos e 26,3\% das espécies, sendo a segunda isca mais visitada. E. surinamensis foi capturada somente nessa essência. Salicilato de metila e eugenol atraíram juntos 2,6\% dos indivíduos. Salicilato de metila atraiu $21 \%$ das espécies, eugenol ,15,8\%. Em geral, 
as espécies apresentaram maior frequiência nos meses chuvosos (janeiro-junho). Os machos freqüentaram as essências durante todo o dia, porém com maior freqüência no período matutino, cujo pico observado foi entre 8 e 10 horas.

Palavras-chave: Euglossinae, Ilha do Cajual, iscas-odores, Maranhão.

\section{INTRODUCTION}

The studies on euglossine bees conducted in Maranhão State were reviewed by Rebêlo \& Silva (1999), who presented a list of the known species in northern Maranhão, using an ecological and biogeographical approach. These authors focused on the diversity of ecosystem and climate found in the state, linking this to regional distribution of the species. They found of euglossine bees in the whole northern part of Maranhão, and also pointed out that species richness was higher in the Amazonian part of the State.

Over the past thirty years, the developmental and settling process in the northern part of Maranhão led to unparalled deforestation of primary vegetation (forests, savannas, and transitional areas). The anthropogenic activity has modified regional ecology, directly influencing the distribution pattern of local fauna, including euglossine bees. Due to this progressive alteration, knowledge of the fauna in the several environments of the State is of great relevance.

One of the areas most disturbed by anthropic intrusion is the coastal zone where Cajual Island, the target study site, is located. There, the primary vegetation has been changed into an early secondgrowth forest called "capoeira". This study aims to determine species richness, relative abundance, daily and annual distribution, and association of the euglossine bees with the essences used employed as bait, as well as to compare Cajual Island with other previously studied areas.

\section{MATERIAL AND METHODS}

\section{Study area}

Cajual Island is located in the inner Maranhão Gulf, western coast of Maranhão State, between $02^{\circ} 26^{\prime} \mathrm{S}$ and $44^{\circ} 03^{\prime} \mathrm{W}$ and about $18 \mathrm{~km}$ from São Luís, the state capital (Fig. 1). The island has about 6,000 ha and is approximately $4 \mathrm{~km}$ away from the municipality of Alcântara, to which it belongs.

The island is part of the Environmental Protection Area of Maranhão's western seashore and was recently incorporated into the Western Hemisphere Shorebird Reserve Network (WHSRN). Cajual Island has muddy and sandy beaches and is surrounded by an extensive estuarine area, the waters thereof, among other factors, offer optimal conditions for mangrove development.
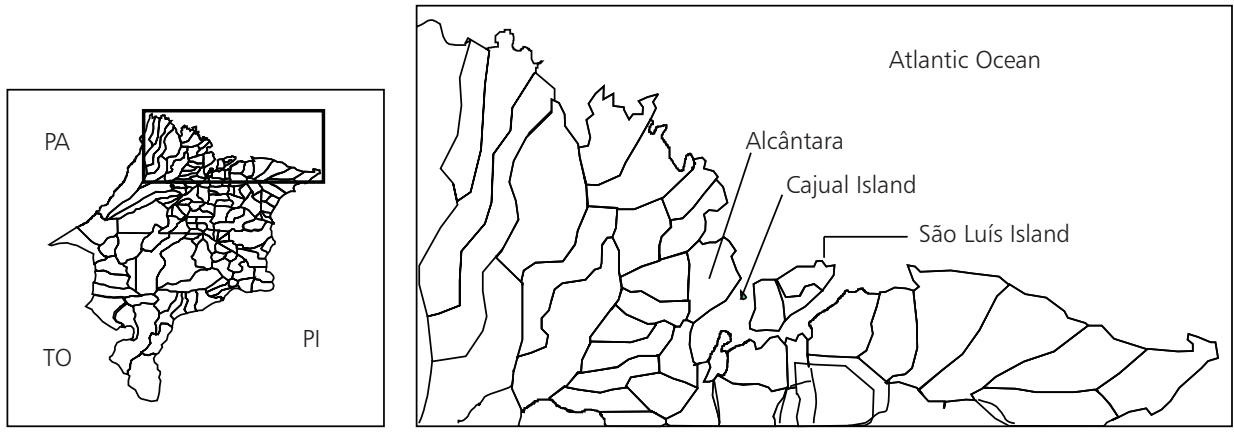

Fig. 1 - Map of the Maranhão State showing Cajual Island, where this research was done. 
The island's vegetation originally comprised moist tropical broadleaf forest and mangrove (IBGE, 1984). As a consequence of economic activity of the population, originally from inland maranhão (small farmers and fishermen), a mixed forest, made up of second-growth forest, babassu palm forest, and other vegetal formations, replaced the original vegetation. Environmental impacts are represented chiefly by agricultural areas, grazing land, and wood extraction for both home building and coal production.

\section{Sampling}

The scent compounds used for baiting bees were cineole, vanillin, methyl salicylate, and eugenol. Baits were hooked $1.5 \mathrm{~m}$ high and set $8 \mathrm{~m}$ from one another. Pellets were soaked with their respective essence every two hours.

Captures were carried out from December 1997 to November 1998, once a month, between 7:00 and 17:00 $\mathrm{h}$. The bees attracted to baits were collected with entomological nets, put into gas chambers containing ethyl acetate, and then deposited in plastic bags labeled with the name of the collector, day, place, hour and bait on which each bee was captured. In the laboratory, the specimens were identified and placed in the entomological collection of the Department of Pathology, Federal University of Maranhão.

The data on temperature and humidity were provided by Companhia Vale do Rio Doce (CVRD) climate station (Fig. 2). At the collecting site, information on overall cloud cover, wind speed, temperature, and relative humidity were also taken.

\section{RESULTS}

A total of 339 male euglossine bees were sampled, comprising 19 species of the following four genera: Euglossa, accounting for $84.4 \%$ and 9 species, Eulaema (10.6\% and 3 species), Eufriesea (2.9\% and 6 species), and Exaerete (2.1\% and 1 specie) (Table 1). The most abundant species was $E$. cordata, which represented $69.9 \%$ of the individuals taken, followed by E. truncata (2.9\%), E. violaceifrons, and E. smaragdina (2.1\%).

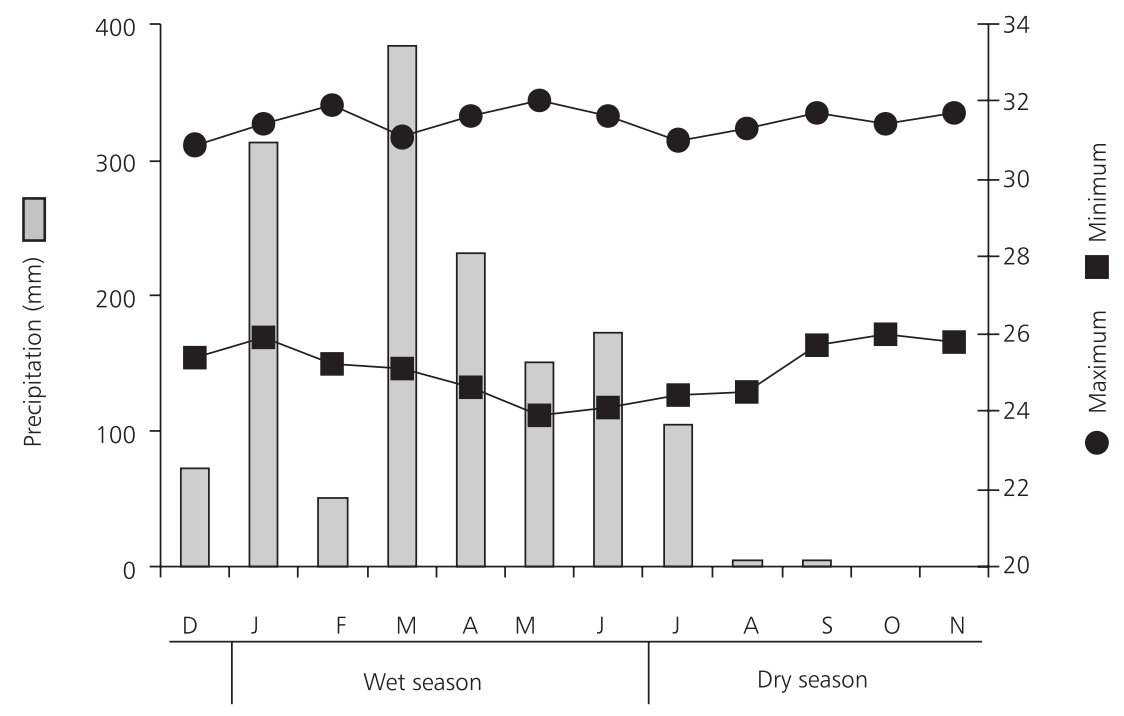

\begin{tabular}{lcccccccccccc}
\hline Months & D & J & F & M & A & M & J & J & A & S & O & N \\
Maximum & 30.9 & 31.4 & 31.9 & 31.1 & 31.6 & 32.0 & 31.6 & 31.0 & 31.3 & 31.7 & 31.4 & 31.7 \\
Minimum & 24.4 & 25.9 & 25.2 & 25.1 & 24.6 & 23.9 & 24.1 & 24.4 & 24.5 & 25.7 & 26.0 & 25.8 \\
Precipitation & 72 & 313 & 51 & 384 & 231 & 150 & 172 & 104 & 5 & 5 & 0 & 0 \\
\hline
\end{tabular}

Fig. 2 - Maximum and minimum temperature values and precipitation, provided by Companhia Vale do Rio Doce (CVRD) climate station, December 1997 to November 1998. 
TABLE 1

Species of euglossine attracted to scent baits on Cajual Island, Maranhão State, from December 1997 to November 1998.

\begin{tabular}{|l|c|cc|c|c|}
\hline \multicolumn{1}{|c|}{ Euglossinae/baits } & Cineole & Vanillin & $\begin{array}{c}\text { Methyl } \\
\text { Salicylate }\end{array}$ & Eugenol & Total \\
\hline E. cordata & 234 & - & - & - & 234 \\
\hline E. fimbriata & 1 & - & - & - & 1 \\
\hline E. gaianii & - & - & 3 & - & 3 \\
\hline E. modestior & 2 & - & - & - & 2 \\
\hline E. piliventris & 1 & - & - & - & 1 \\
\hline E. securigera & 2 & - & - & - & 2 \\
\hline E. towsendi & 2 & - & - & - & 2 \\
\hline E. truncata & 18 & 16 & - & - & 34 \\
\hline E. violaceifrons & 7 & - & - & - & 7 \\
\hline E. elegans & - & - & - & 1 & 1 \\
E. magroglossa & 1 & - & - & - & 1 \\
\hline E. mussitans & 1 & - & - & - & 1 \\
\hline E. pulchra & 1 & - & 3 & - & 4 \\
\hline E. superba & - & - & 1 & - & 1 \\
\hline E. surinamensis & - & 2 & - & - & 2 \\
\hline E. cingulata & - & 4 & - & 6 & 10 \\
\hline E. meriana & 1 & - & 2 & - & 3 \\
E. nigrita & 20 & 3 & - & - & 23 \\
\hline E. smaragdina & 4 & 1 & - & 2 & 7 \\
\hline Individuals & 295 & 26 & 9 & 9 & 339 \\
\hline Species & 14 & 5 & 4 & 3 & 19 \\
\hline
\end{tabular}

The most effective scent was cineole, which baited $87 \%$ of the individuals and $73.7 \%$ of the species (Table 1 and Fig. 3). It was visited solely by $E$. cordata, E. townsendi, and E. violaceifrons (Table 1). Vanillin baited $7.6 \%$ of the individuals and $26.3 \%$ of the species, representing the second most attractive bait. E. surinamensis was captured only by this bait. Methyl salicylate and eugenol attracted together $2.6 \%$ of the individuals. Methyl salicylate alone baited $21 \%$ of the species, attracting $E$. pulchra and E. meriana as the most frequent species, and E. gaianii and E. superba as exclusive visitors. Eugenol baited $15.8 \%$ of the species (Table 1). Cineole was significantly more attractive than all other baits together $\left(c^{2}=185.84\right.$ and $\left.p<0.01\right)$.

The species were captured mostly in the rainy season (January-June) $\left(c^{2}=40.38\right.$ and $\left.p<0.01\right)$. The peaks of number of individuals were detected in
March and April, whereas peaks for number of species were in April and June (Table 2 and Fig. 4). E. cordata occurred year round, however it was more abundant between March and May. The low number of individuals of this species in December was partially due to rain on the sampling day. E. nigrita, $E$. cingulata, and $E$. truncata visited the baits in a restricted period of the year (Table 2), from February to August. The remaining species were found scattered throughout the year (Table 2). All Eufriesea species occurred only in the rainy season, in either one, two, or three months. The mean precipitation monthly values of rainfall correlated positively with individual abundance numbers $(\mathrm{r}=0.73)$.

Data on the hourly activity showed that euglossine bees visited the baits all day long, but were more frequently taken in the morning period $\left(c^{2}=157.4\right.$ and $\left.\mathrm{p}<0.01\right)$. 


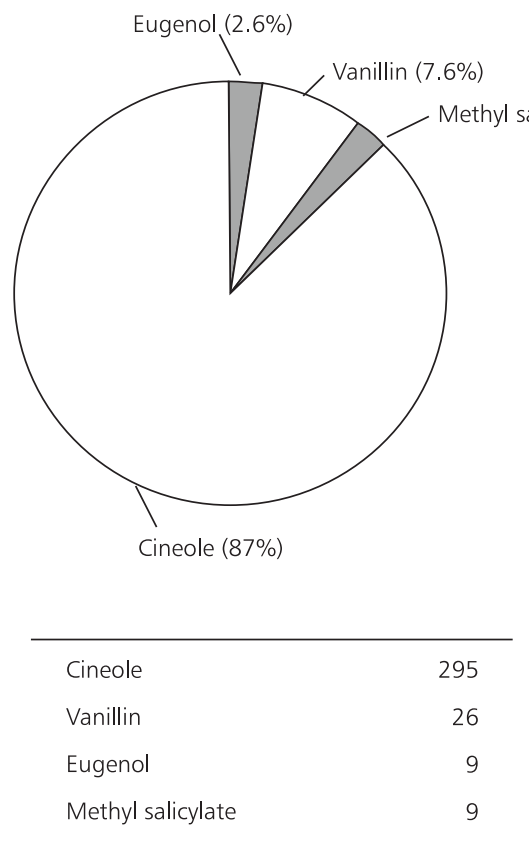

Fig. 3 - Attraction pattern of euglossine species to the odorous substances collected on Cajual Island, Maranhão, from December 1997 to November 1998.

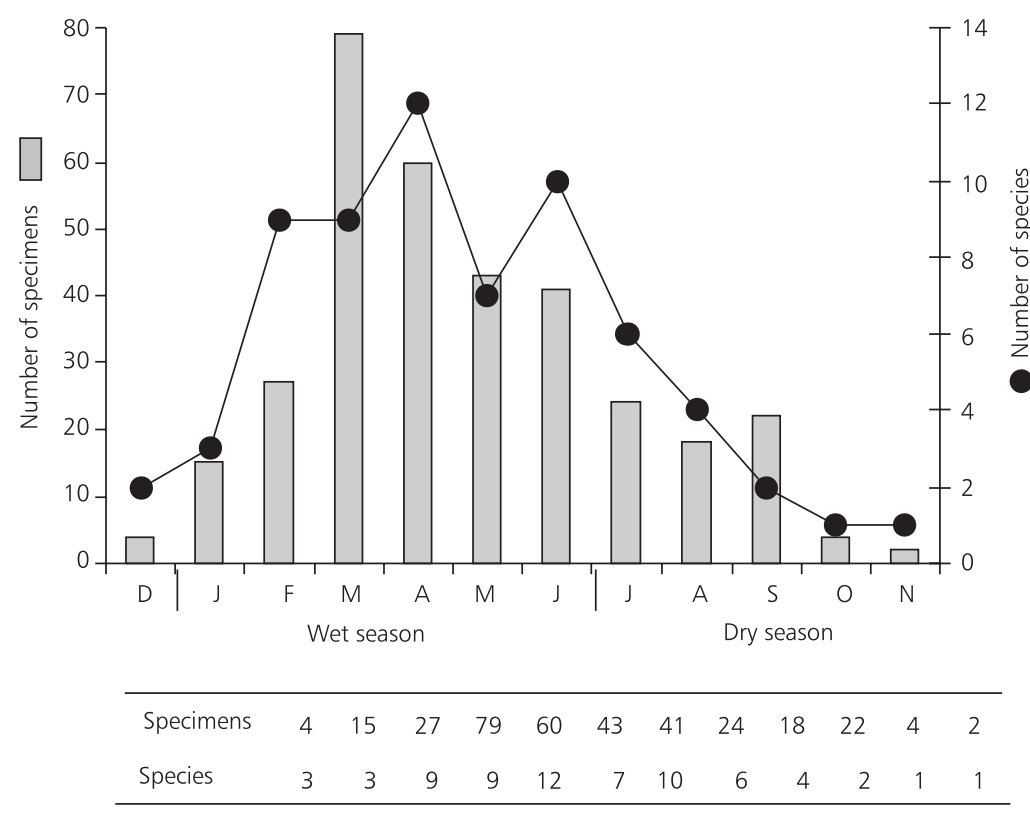

Fig. 4 - Season distribution of the euglossine bees collected on Cajual Island, Maranhão, from December 1997 to November 1998. 
TABLE 2

Seasonal distribution of euglossine species collected at scent baits on Cajual Island, Maranhão, from December 1997 to November 1998.

\begin{tabular}{|l|c|c|c|c|cc|cc|c|c|c|c|c|}
\hline \multicolumn{1}{|c}{ Species/months } & D & J & F & M & A & M & J & J & A & S & O & N & Total \\
\hline E. cordata & 3 & 10 & 18 & 65 & 34 & 28 & 20 & 14 & 15 & 21 & 4 & 2 & 234 \\
\hline E. fimbriata & - & - & - & - & - & - & 1 & - & - & - & - & - & 1 \\
\hline E. gaianii & - & - & - & - & 1 & - & 2 & - & - & - & - & - & 3 \\
E. modestior & - & - & - & - & - & - & 2 & - & - & - & - & - & 2 \\
\hline E. piliventris & - & - & - & - & 1 & - & & - & - & - & - & - & 1 \\
\hline E. securigera & - & - & - & - & - & 1 & - & 1 & - & - & - & - & 2 \\
\hline E. towsendi & - & - & 1 & 1 & - & - & - & - & - & - & - & - & 2 \\
\hline E. truncata & - & - & 1 & 7 & 12 & 4 & 6 & 3 & 1 & - & - & - & 34 \\
\hline E. violaceifrons & - & - & 1 & - & 3 & 1 & 1 & 1 & - & - & - & - & 7 \\
\hline E. elegans & - & - & - & - & 1 & - & - & - & - & - & - & - & 1 \\
E. magroglossa & - & - & - & - & 1 & - & - & - & - & - & - & - & 1 \\
E. mussitans & - & - & 1 & - & - & - & - & - & - & - & - & - & 1 \\
\hline E. pulchra & - & - & 2 & 1 & 1 & - & - & - & - & - & - & - & 4 \\
\hline E. superba & - & - & - & 1 & - & - & - & - & - & - & - & - & 1 \\
\hline E. surinamensis & - & - & - & 1 & 1 & - & - & - & - & - & - & - & 2 \\
\hline E. cingulata & - & 1 & 1 & 1 & 3 & 3 & 1 & - & - & - & - & - & 10 \\
\hline E. meriana & - & - & - & 1 & - & - & 1 & - & 1 & - & - & - & 3 \\
\hline E. nigrita & 1 & 4 & 1 & 1 & 1 & 5 & 6 & 4 & - & - & - & - & 23 \\
\hline E. smaragdina & - & - & 1 & - & 1 & 1 & 1 & 1 & 1 & 1 & - & - & 7 \\
\hline Total of individuals & 4 & 15 & 27 & 79 & 60 & 43 & 41 & 24 & 18 & 22 & 4 & 2 & 339 \\
\hline Total of species & 2 & 3 & 9 & 9 & 12 & 7 & 10 & 6 & 4 & 2 & 1 & 1 & 19 \\
\hline
\end{tabular}

The most eclectic species was E. cordata, which visited the baits in all periods, with peaks observed between 8:00 and 10:00 h. corresponding to the general activity peak of euglossine bees on Cajual Island (Fig. 5). The large numbers of individuals of $E$. cordata were responsible for the activity peak in the afternoon period (14:00-16:00 h). E. truncata visited the baits in almost all periods, but were absent between 12:00 and 13:00 h. In general, Eufriesea and Eulaema species were limited to a short period of the day. E. meriana visited the baits early in the morning. At that time (6:00-7:00 h) the most frequently found species were E. cordata, E. truncata, and Eulaema.

\section{DISCUSSION}

The fauna of euglossine bees of Cajual Island is similar to that found in the neighboring muni- cipality of Alcântara (Gonçalves et al., 1996), about $4 \mathrm{~km}$ away, as well as that encountered in other areas with similar phytogeographic and climatic features in the northern part of the State (Rebêlo \& Silva, 1999), however, it was quite different from that of São Luís Island bee fauna, in the Maranhão Gulf zone. This could possibly be due to the presence of residual moist forests there, which are characteristically Amazonian areas. The distance between the islands of Cajual and São Luís is approximately $18 \mathrm{~km}$ in a straight line by the sea, which may constitute a barrier to the migration. On the other hand, the short distance between Cajual Island and Alcântara, led us to suppose that some specimens caught on the former, would come from the latter to forage. Euglossine bees are able to fly over $5 \mathrm{~km}$ (Janzen et al., 1982). Many species found on Cajual Island also occur in different brazilian biogeographic areas. 


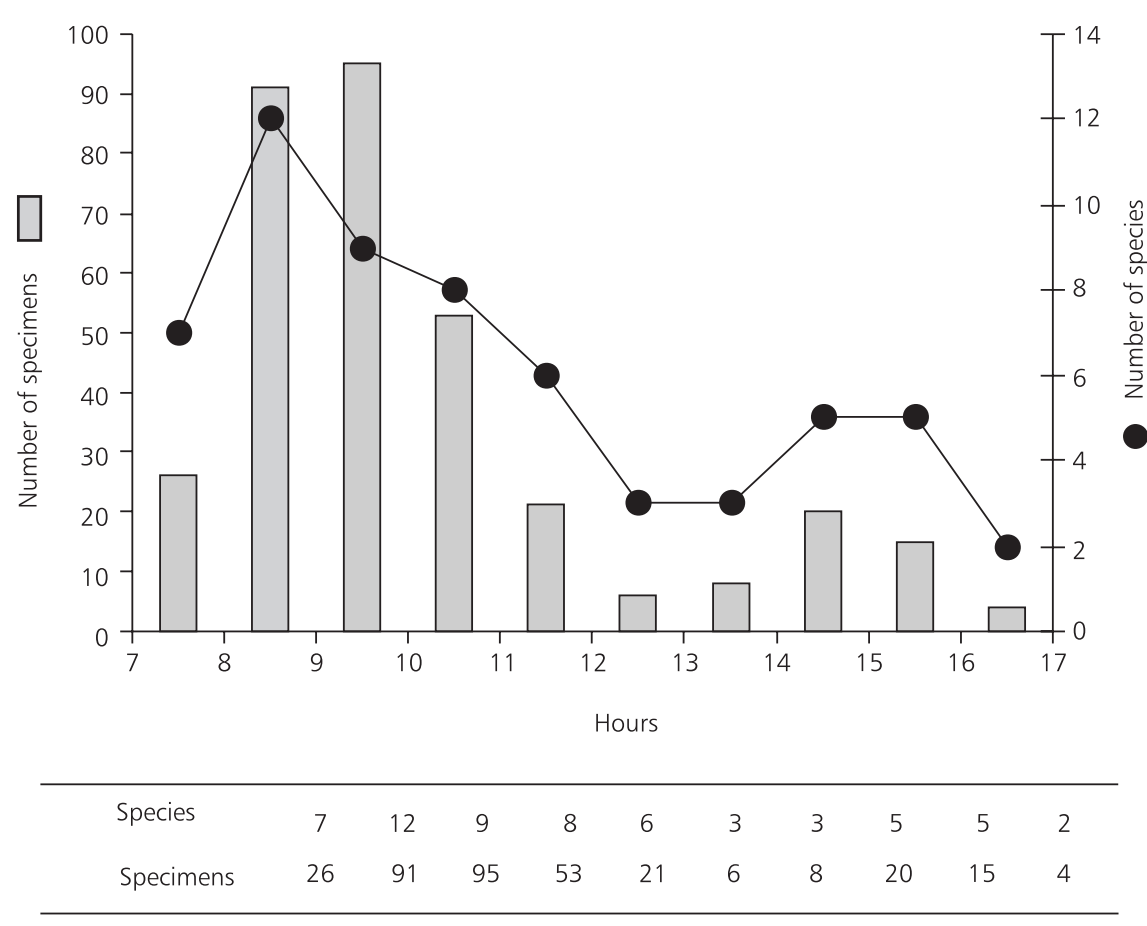

Fig. 5 - Hourly activity of the euglossine species collected on Cajual Island, Maranhão, from December 1997 to November 1998 .

Thus, they seem to support a wide climatic variation, as well as geographic range. Changes in abiotic factors, such as a decrease in mean moisture rate, and an increase in temperature (28$34^{\circ} \mathrm{C}$ ) throughout the year (data obtained at the sampling site) in addition to deforestation seemed to be no barrier to the occurrence of the species there. Conversely, these same factors markedly influenced daily activity.

$E$. cordata, the most abundant species, is often associated with open areas in which the air is somewhat drier (Ducke, 1902), such as savannas, xeric shrublands, river-edge vegetation, grasslands and second growth forest. It is yet to be detected in wet Amazonian areas. In inventories conducted in Central Amazonia using scent baits, this species was not found (Becker et al., 1991; Morato et al., 1992; Oliveira \& Campos, 1995). Nevertheless, in southwestern Amazonia (Buriticupu, MA), as reported by Silva \& Rebêlo (1999), as well as in sub-Amazonian areas (Wittman et al., 1988; Raw, 1989; Rebêlo \& Garófalo, 1991, 1997; Neves \&
Viana, 1999), E. cordata was found in abundance using cineole. This is despite the fact that in Buriticupu, as an Amazonian Broadleaf forest (Hueck, 1972), it tolerates a 5-6 month drought period (Silva \& Rebêlo, 1999) similar to those of semi-humid areas found in most of Maranhão, specially in the near portion of Piauí State.

This northwestern influence may account for the occurrence of E. cordata in that region. The abundance of this species in Cajual Island, and in other equivalent areas in the state (Rebêlo \& Cabral, 1997; Rebêlo \& Silva, 1999), strengthen the hypothesis that $E$. cordata may be a species favored by conditions in these dry and altered environments.

In general, the attraction pattern to the baits on Cajual Island was comparable to those found in most studies using scent baits.

Most of the species visited cineole, chiefly E. cordata $(100 \%)$, corroborating the works in which this species was strongly attracted to the same essence (Raw, 1989; Rebêlo \& Garófalo, 
1991; Rêbelo \& Cabral, 1997; Neves \& Viana, 1999; Silva \& Rebêlo, 1999). E. nigrita, another species abundantly captured in the island, was attracted by both cineole and vanillin. Similar results were found by Rebêlo \& Garófalo (1991) and Silva \& Rebêlo (1999).

Some exceptions to the general attraction pattern were observed. The only two individuals of E. townsendi limited themselves to cineole. This diverged from what was found in Central America by Ackerman (1989), who showed species visited solely methyl salicylate. E. truncata that this was attracted only to cineole and vanillin, the most effective scents in this study, unlike results found in northern São Paulo by Rebêlo \& Garófalo (1991, 1997) and in Amazonian Maranhão by Silva \& Rebêlo (1999), where cineole and eugenol were the most effective.

E. smaragdina was attracted to almost all the essences, especially cineole. In the current study, methyl salicylate was not attractive to $E$. smaragdina, which corroborates the result found for the Amazonian and eastern parts of Maranhão (Silva \& Rebêlo, 1999; Rebêlo \& Cabral, 1997). In the Costa Rican deciduous forests, E. smaragdina was attracted to all baits employed, including methyl salicylate (Janzen et al., 1982). This chemical substance was also used in work carried out in the States of São Paulo (Rebêlo, pers. obs.) and Bahia (Neves \& Viana, 1999), but did not attract any male euglossine bees in those areas, as also noted for other parts of the neotropical region. It is presumed that the three known orchid species producing this scent (Williams \& Whitten, 1983), are distributed restrictedly and that the interface orchid-scenteuglossine must exist, in addition to other factors. The age, genetic differences among euglossine populations, and the essence's active substance and availability (Ackerman, 1989), as well as minor molecular adjustments, such as the lack of a chemical compound (Williams \& Dodson, 1971), may all affect and act on geographic preferences for the scents potential attractiveness.

The bee preference for essences as baits must be carefully evaluated, as there are numerous intrinsic and extrinsic factors influencing this choice. Climatic parameters such as wind or direct insolation may affect scent volatilization level at collection sites. Cineole is a very volatile substance (low molecular weight) compared to eugenol and for that reason is capable of generating an overwhelmingly greater attraction range, when compared to the dispersing scope of eugenol. This means that a highly volatile substance could attract an eclectic species (those attracted by several essences) from further away. However, when approaching the source the specimen could change its original route and land on an adjacent bait, whose scent is more pungent, regardless of its shorter range of attraction. An additional point is that some species associate with only one substance in a given geographic area and with more than one in other parts of their range. Thus, the term "preference" would be inexact. In this case, to assess the actual preference for any substance used as bait, a specific study for that purpose must be designed.

Among the species found on the island, $E$. cordata was the only one considered annual, even though it was clearly associated with the rainy season. In other similar areas like the municipality of Barreirinhas, E. cordata was also found year round (Rebêlo \& Cabral, 1997).

In the semi-arid region of Bahia, euglossine males visited the baits right after the rainy season, and was believed that those visits were supported by blossoms, mild temperatures and higher humidity values observed in that period (Neves \& Viana, 1999).

In the semideciduous forests of northeastern São Paulo, where the four seasons are distinct, few males landed on the baits in the colder and drier months (Rebêlo \& Garófalo, 1991). Garófalo (1987) observed that E. cordata did not build nests during this season in São Paulo, whereas Rebêlo \& Garófalo (1991) reported an increased number of individuals of $E$. cordata after this period. Climatic parameters certainly determine the occurrence of this species in the subtropics, while in the tropics, precipitation plays a marked role in the incidence of all euglossine bee species. Thus, the factors which either directly or indirectly affect the euglossine seasonal pattern are expected to vary according to the area studied.

The information on hourly activity of the species sampled at Cajual Island showed that the temperature was a decisive factor in male activity at the baits. In general, the bees arrived at the baits 
early in the morning, with peaks between 8:00 and 10:00 $\mathrm{h}$, decreasing afterwards, according to the temperature increase and moisture decrease by noon. These results were similar to those found by Braga (1976) in the area of Manaus, Central Amazonia. In Amazonian Maranhão, although data were restricted to the morning period, the abundance peak was occurred late in the morning, between 10:00 and 11:00 h. In that region, temperature variation is very slight (Silva \& Rebêlo, 1999). In the two Amazonian areas investigated by Oliveira \& Campos (1995), the euglossine males were active between 9:00 and 16:00 $\mathrm{h}$, when the temperatures ranged from $24.5^{\circ} \mathrm{C}$ to $27^{\circ} \mathrm{C}$. In São Paulo in the hotter seasons, activity at the baits began at temperatures higher than $18^{\circ} \mathrm{C}$, at 8:00-9:00 h (pers. obs.), contrasting with the results found for winter, when the males started visiting the baits only after 10:00 $\mathrm{h}$.

In short, no kind endemism was observed. Most species found on Cajual Island are widely distributed in the Brazil savanna; some are common to both savanna and the wet Amazonian environment. Others are confined to the latter.

\section{REFERENCES}

ACKERMAN, J. D., 1989, Geographic and seasonal variation in fragrance choices and preferences of male Euglossinae bees. Biotropica, 21: 340-347.

BECKER, P., MOURE, J. S. \& PERALTA, F. J. A., 1991, More about euglossine bees in Amazonian Forest Fragments. Biotropica, 23(4b): 586-591.

BRAGA, P. I. S., 1976, Atração de abelhas polinizadoras de Orquidacea com auxílio de iscas-odores na campina, campinarana e floresta tropical úmida da região de Manaus. Ciência e Cultura, 28: 767-773.

DUCKE, A., 1902, As espécies paraenses do gênero Euglossa Latr. Bio. Mus. Goeldi, 3: 561-575.

GARÓFALO, C.A., 1987, Aspectos biômicos e sociológicos de Euglossa (Euglossa) cordata (Hymenoptera: Apidae: Euglossini). Tese de Livre Docência, Faculdade de Filosofia e Letras de Ribeirão Preto - SP.

GONÇALVES, S. de J. M., RÊGO, M. \& ARAÚJO, A. de, 1996, Abelhas sociais (Hymenoptera: Apidae) e seus recursos florais em uma região de mata secundária, Alcântara, MA, Brasil. Acta Amazônica, 26(1/2): 55-68.

HUECK, K., 1972, As florestas da América do Sul. Editora da Universidade de Brasília/Editora Polígono S.A., São Paulo.

IBGE, 1984, Atlas do Maranhão. Edição em convênio com o Governo do Estado do Maranhão, Rio de Janeiro.
JANZEN, D. H., De VRIES, P. G., HIGGINS, M. L. \& KIMSEY, L. S., 1982, Seasonal and site variation in Costa Rican Euglossine bees at chemical baits in lowland deciduous and evergreen forests. Ecology, 63: 6674.

MORATO, E. F., CAMPOS, L. A. O. \& MOURE, J. S., 1992, Abelhas Euglossini (Hymenoptera, Apidae) coletadas na Amazônia Central. Rev. Bras. Ent., 36(4): 767-771.

NEVES, E. L. \& VIANA, B. F., 1999, Comunidade de machos de Euglossinae (Hymenoptera: Apidae) das matas ciliares da margem esquerda do médio Rio São Francisco, Bahia. An. Soc. Entomol. Brasil, 28(2): 201-210.

OLIVEIRA, M. L. \& CAMPOS, L. A. O., 1995, Abundância, riqueza e diversidade de abelhas Euglossinae (Hymenoptera, Apidae) em florestas contínuas de terra firme na Amazônia Central, Brasil. Revta Bras. Zool., 12(3): 547556.

RAW, A., 1989, The dispersal of euglossine bees between isolated patches of eastern Brazilian wet forest (Hymenoptera, Apidae, Euglossini). Rev. Bras. Ent., 33(1): 103-107.

REBÊLO, J. M. M. \& CABRAL, A. J., 1997, Abelhas Euglossinae de Barreirinhas, Zona do litoral da Baixada Oriental Maranhense. Acta Amazônica, 27: 145-152.

REBÊLO, J. M. M. \& GARÓFALO, C. A., 1991, Diversidade e sazonalidade de machos de Euglossini (Hymenoptera: Apidae) e preferências por iscas-odores em um fragmento de floresta no sudeste do Brasil. Rev. Brasil. Biol., 51(4): 787-799.

REBÊLO, J. M. M. \& GARÓFALO, C. A., 1997, Comunidade de machos de Euglossini (Hymenoptera: Apidae) em matas semidecíduas do nordeste do Estado de São Paulo. An. Soc. Entomol. Brasil., 26(2): 243-255.

REBÊLO, J. M. M. \& SILVA, F. S., 1999, Distribuição das abelhas Euglossini (Hymenoptera, Apidae) no Estado do Maranhão, Brasil. An. Soc. Entomol. Brasil, 26(3): 379-391.

SILVA, F. S. \& REBÊLO, J. M. M., 1999, Euglossine bees (Hymenoptera, Apidae) of Buriticupu, Amazonia of Maranhão, Brazil. Acta Amazônica, 29(4): 472-486.

WILLIAMS, N. H. \& DODSON, C. H., 1971, Selective attraction of male euglossine bees to orchid floral fragrances and its importance in long distance pollen flow. Evolution, 26: 84-95.

WILLIAMS, N. H. \& WITTEN, W. M., 1983, Orchid floral fragrances and male euglossine bees. Methods and advances in the last sesquidecade. Biol. Bull., 164: 355-395.

WITTMAN, D., HOFFMANN, M. \& SCHOLZ, E., 1988, Southern distribution of euglossine bees in Brazil linked to habitats of the Atlantic and Subtropical rain forest (Hymenoptera, Apidae, Euglossini). Ent. Gener., 14(1): 5360. 